\title{
CONDUCTING ENGLISH LEARNING ACTIVITIES BY IMPLEMENTING TELEGRAM GROUP CLASS DURING COVID-19 PANDEMIC
}

\author{
Dian Arsitades Wiranegara ${ }^{1}$ and Sohibul Hairi ${ }^{2}$ \\ (dwiranegara@gmail.com) \\ ${ }^{1}$ English Literature Department \\ Universitas Islam Negeri Maulana Malik Ibrahim Malang \\ ${ }^{2}$ English Literature Department \\ Universitas Islam Negeri Maulana Malik Ibrahim Malang
}

\begin{tabular}{|c|c|}
\hline ARTICLE & ABSTRACT \\
\hline $\begin{array}{l}\text { Mobile Assisted Language } \\
\text { Learning, Telegram Group } \\
\text { \& Teacbing and Learning } \\
\text { by Using Group Chat }\end{array}$ & $\begin{array}{l}\text { The use of telegram can be used to hold a meeting just like the regular } \\
\text { class conducted. Teacher can still observe all members of the group- } \\
\text { students-belong to the class once both parties start to chat or to keep } \\
\text { online within the chat in telegram group. Therefore, every meeting within } \\
\text { the group, teacher can share his or her teaching material into the group and } \\
\text { discuss it along with the students. This also means that the use of social } \\
\text { media group such as: whatsapp or telegram group can help learners to } \\
\text { experience a different way of conducting teaching and learning process. } \\
\text { However, the process may take a while compared to the face-to-face } \\
\text { weekly regular class. This distance class, of course, can be a new experience } \\
\text { by both teacher and students as it needs further investigation about how } \\
\text { this can be conducted accordingly. Nonetheless, during these four } \\
\text { meetings conducted individually at home, both teacher and students are } \\
\text { still able to catch up all the material given within the social media group. } \\
\text { As a result, in order to achieve the effective learning process of English } \\
\text { language class during the Covid-19 pandemic, the distance class should not } \\
\text { burden the students as long as the learning process can be conducted } \\
\text { efficiently. Hence, by using telegram group, teacher and students can keep } \\
\text { in touch or communicate intensively in discussing the teaching material. At } \\
\text { the end of teaching and learning process, students can later be given a } \\
\text { chance to improve their learning strategy to become a long life learner } \\
\text { despite any condition experienced by them. }\end{array}$ \\
\hline
\end{tabular}

\section{INTRODUCTION}

The use of social media group to support the distance class has become inevitably practical. This is in line with the plan of adapting any learning strategy where both teachers and students can work together to conduct the distance class. Nonetheless, they are not actually left alone to keep the learning process run. For this reason, the social media group learning strategy can be developed to involve as well as to encourage students to be active in the process of teaching and learning. This can 
JEASP

Journal of English for Academic and Specific Purposes

Volume 3 Number 2, December, 2020

be developed to involve as well as to encourage students to be active in the process of teaching and learning. Though the class is not conducted regularly, students can fully contribute in this process by the help of telegram group class. This social media group can also be used

The online class was forced to be conducted totally from home or from the students' respective home since the covid-19 pandemic's quarantine issued on the 16 th of March 2020. This plague has been inevitable occurred throughout the country since the beginning of this year. However, the disease has not yet seriously considered contagious pandemic by the Ministry of Health. As a result, most regions, even in East Java province, were not ready to deal with this global outrage, and every party, even the educational one, must be readied to take action in order to cut down the contagion of covid-19. Nonetheless, this is not the issue that is discussed in this paper. Whether ready or not, it has become everyone's obligation to be aware of practicing the advanced technology. In this case, the online class of English Language program at one of the Islamic campus has also come along to adapt with the latest situation.

Hence, to deal with newly condition of the regular class at the campus, the government also gave instructions through the directorate general of Islamic higher education's official letter, issued on March 26, 2020, that instructs all the learning processes are conducted online. For this reason, all the lecture and class are done from home in order to avoid the contagion of the virus. Henceforth, it is time for all teachers and students to adapt the process of learning by using any tools or technological application that correspond to the learning process' need.

Getting used to this newly process of online learning can be referred to the sociocultural as well as the technological changes which has been echoed for several years then and ahead. Hence, a plan of conducting teaching and learning of the 4.0 era is no longer a discourse that has always been discussed before. In fact, we are all facing it today and forced to practice it.

In order to conduct online class program, there are several information and communications technology (ICT) applications which can be applied. As Dumiyati \& Wardhono (2017:1) have stated that the development of information technology and computers are very fast, various community services has implemented ICT. In the world education is known as e-learning. On e-learning learning, the Internet is a medium multi-faceted, on the one hand the Internet can be used to communicate interpersonal for example by using e-mail and chat as a means of inter-personal communication (oneto-one communications), on the other hand with e-mail as well can communicate with more than one person or a group of other users (one-to-many communications). 


\section{JEASP}

Journal of English for Academic and Specific Purposes

Volume 3 Number 2, December, 2020

The internet has the ability facilitate discussion and collaboration activities by a group of people. Furthermore, with its ability to hold communications face to face (teleconference), possible internet users can communicate in a manner audiovisual so that the implementation is possible verbal and non-verbal communication in real time (Sa'ud, 2008: 189). The university also implements elearning in order to hold online class in this time of social quarantine or lockdown. Other social media applications are also encouraged to be used for distance or online class such as: Zoom cloud (one-tomany communications) as seen on teleconference, WhatsApp group and also Telegram group (one-tomany communication) by using text messages that can be read and seen by all members of the same group. Therefore, in order to describe the process of teaching and learning by using telegram group chat, the primary review of mobile-assisted learning and the report of regular class program have been used to support the description of the process found from this paper.

\section{Mobile-Assisted Language Learning}

Today's language teaching and learning has been moving forwards to a new direction as Wardhono \& Spanos (2018: 148) have called it as mobile-assisted language learning, in short (MALL). It has become a learner-centered and autonomous (Lixun, 2017). Since the mid-1990s, MALL has focused on the exploitation of five mobile technologies: pocket electronic dictionaries, personal digital assistants (PDAs), mobile phones, MP3 players, and most recently ultra-portable tablet PCs (Burston, 2013). A study conducted by Deng and Shao (2011) indicated that there was a high readiness of students to undertake mobile learning in their everyday life (Guo, 2015).Social networking is one tool which can assist teachers and learners to access information and facilitate the learning of English (Srinivas, 2010). According to Heidar \& Kaviani (2016), one of the technologies that can be used to help learner in learning a foreign language is Telegram.

Telegram has become one of the most famous online social media networks among the university students (Heidar \& Kaviani, 2016). Telegram has channels and bots to access information with the teacher. Omidi \& Fooladgar (2015) in (Wardhono \& Spanos, 2018: 148), its intermediary server can actually handle all encryption and communication with the Telegram API for the users. The users communicate with this server via the Telegram API. The server calls that interface as Bot API (https://core.telegram.org/bots/api). Therefore, this social media application can be helpful to accommodate the teaching and learning process by both teacher and students.

This social media group can also be used to hold a meeting just like the regular class conducted. Teacher can still observe all members of the group—students—belong to the class once 
JEASP

Journal of English for Academic and Specific Purposes

Volume 3 Number 2, December, 2020

both parties start to chat or to keep online within the chat in telegram group. Therefore, every meeting within the group, teacher can share his or her teaching material into the group and discuss it along with the students. This also means that the use of social media group such as: whatsapp or telegram group can help learners to experience a different way of conducting teaching and learning process.

\section{Regular Class Program Online}

The online regular class, of course, can be a new experience by both teacher and students as it needs further investigation about how this can be conducted accordingly. Nonetheless, during these four meetings conducted individually at home, both teacher and students are still able to catch up all the material given within the social media group. As a result, in order to achieve the effective learning process of English language class during the Covid-19 pandemic, the distance class should not burden the students as long as the learning process can be conducted efficiently.

As Markova et al (2016: 686) stated that distance learning (DL) has become easily accessible and can give a significant impact to the use of information and communication technologies (ICT) in tertiary institutions. Nowadays, online is the fastest growing sector of higher education (Means, Toyama, Murphy, Bakia, \& Jones, 2010), gaining popularity both on and off campus. This modern technology can provide enormous opportunities for effective communication. This can be asserted that in the virtual learning environment communication and interaction can be more student-centered, less intimidating, and encourage greater participation than classroom interactions (Allen et al., 2004; $\mathrm{Ni}, 2013)$. Furthermore, some evidence has been also provided that the quality and quantity of communication give a raise to the overall student learning perception and satisfaction (Sloan, 2002). Hence, this can actually provide more opportunities for students to keep in touch with the teacher easily as time and place barrier is no longer a problem in distance and online learning.

The Regular English Class is conducted once in a week. All students of Non-English department, started from the third semester and forth semester, are assigned and required to take this program. The aims of this program are to train students with the Basic English course that is related to the student's background knowledge. The competences taught at this program are reading and writing. By the end of this regular program, it is hoped that students can actually develop their reading skills as well as their writing skills. At first and most of the time, the class is held conventionally in the classroom. However, since this pandemic plague, it is required to be conducted online or distance learning. 
In order to meet the students' competence of the program, the standard competence's instructions has been presented to the students in the beginning of the first meeting. Therefore, both teacher and the students can arrange and implement the learning process efficiently and effectively in accordance with the course outline based on the syllabus.

\section{METHOD}

A series of simple online class can be developed for a medium cohort of the second year or the third semester of non-English department students using only standard tools available in any virtual learning environment (VLE). In this case, Telegram group class has been used as the platform for development and delivery of the materials. Since the teaching and learning activities were entirely conducted online it is time for both teachers and students to get used with the new activities. Though these activities conducted online, they have to be the same things as the normal learning activities: preteaching, whilst teaching and post teaching.

There are a total of 104 students and they divided into four classes. Each class has one telegram group and of course, they have been involved in this phase of an action research-based study designed to adapt to findings and student feedback from the process. Therefore, in order to meet the objective of this program these three techniques can be elaborated as follows:

\section{Pre-Teaching is to prepare Telegram Group Learning}

Both teacher and students have agreed to use telegram group application in order to conduct teaching and learning process. The group was intended to be used to communicate and coordinate with all students in a class. In this online classroom, by using telegram group, the teacher asked one of the representative of the students, or the chief of the class, to install the telegram application, then he or she can inform all the students to join the group online.

This is based the teacher's instruction so that the purpose to meet the objective the teaching and learning competence can be done effectively, though this might even need more further investigation of how effective to conduct an online group class. Nonetheless, through this short discussion of this paper, the way to conduct regular class by using telegram group can be an open path for further research.

In conducting the pre-teaching by using telegram group, the teacher starts by greeting as he or she does with the regular class. The teacher also gives the introduction of the topic as well as the instruction that completes the topic of the learning process. By doing this, the teacher can actually 
JEASP

Journal of English for Academic and Specific Purposes

Volume 3 Number 2, December, 2020

guide students to understand the teaching material as well as maintain or monitor the interaction during the teaching and learning process. Therefore it can lead to help students to have a background knowledge through this process.

Before heading to the while teaching activity, another activities that can be included in this section is through sharing and presenting the video. It, of course, should be related to the topic presented and discussed during the class. During this activities, it can be considered that any related material either it is visual or textual, should be presented in a simple way. This can be seen as the captured image below.

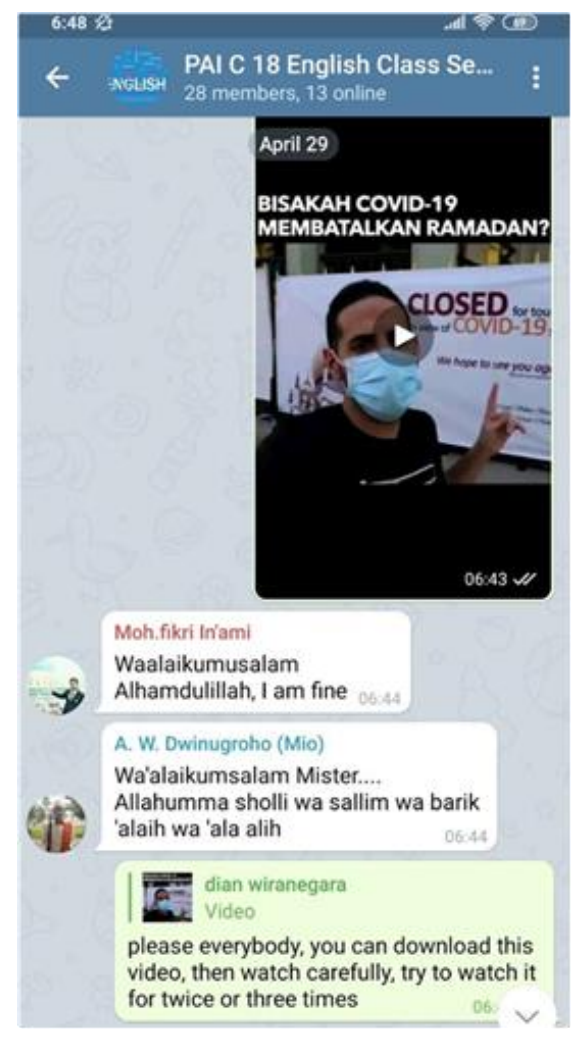

\section{Whilst-Teaching}

As the video shared into the telegram group, the students can watch it and try to acquire the information provided from the video. The teacher can start to ask about the students' response towards the content of video. This can be started by asking about their opinion about the content of the video. Then, it can be followed by listing the possible questions related to the topic. 


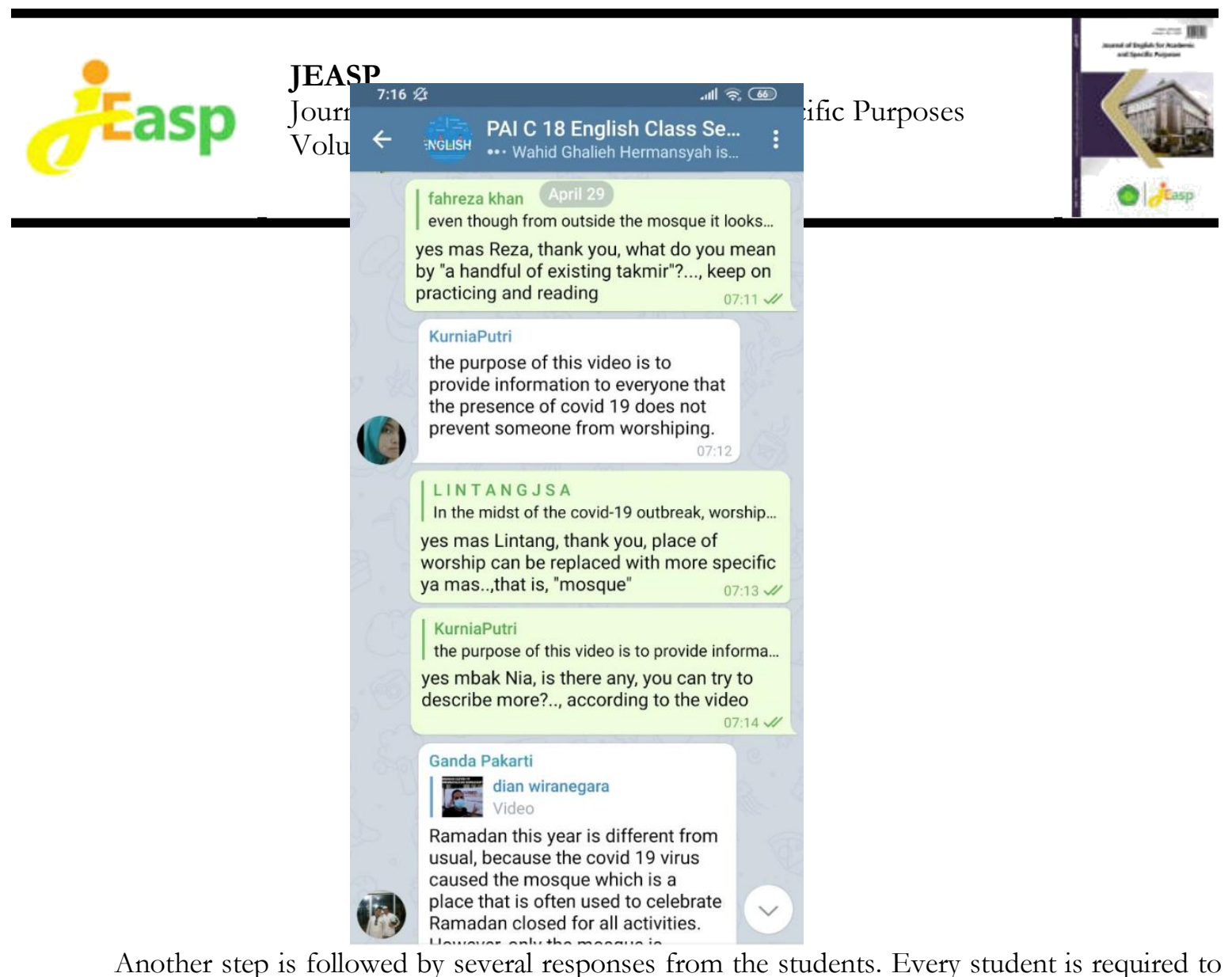

Another step is followed by several responses from the students. Every student is required to give his or her opinion towards the content of the video by writing or typing by using a telegram group chat. Hence, this can result or trigger them to give his or her own opinion so that the teacher can also give a direct feedback or response of the students' opinion. Of course, as one chat by the student is responded directly as one of them post his/ her opinion, one chat is commented and corrected by the teacher. This is done for individual task done by using telegram group chat, as shown at this screenshot below:

By giving a direct response or feedback, both teacher and students can maintain their interaction effectively. Nonetheless, much effort, such as: the stable internet connection as well as both parties, teacher and students were also needed to reach the teaching process done. As it is shown above, once a student reacts and gives his or her opinion, it can become his or her writing practice as it is also a skill taught in regular English class. The teacher has to assure that his or her writing opinion has to be in line with the story given. Therefore, a teacher can effectively identify his or her students' comprehension in getting the information provided from the material given by the teacher.

Once the student has posted his or her writing, other students belong to the group class can also read other student's opinion. As his or her opinion was commented by the teacher, he or she can directly revise his or her opinion, then repost it to telegram group. As a student has worked on the revision, the teacher also gives his reply. As shown below: 
JEASP

Journal of English for Academic and Specific Purposes

Volume 3 Number 2, December, 2020

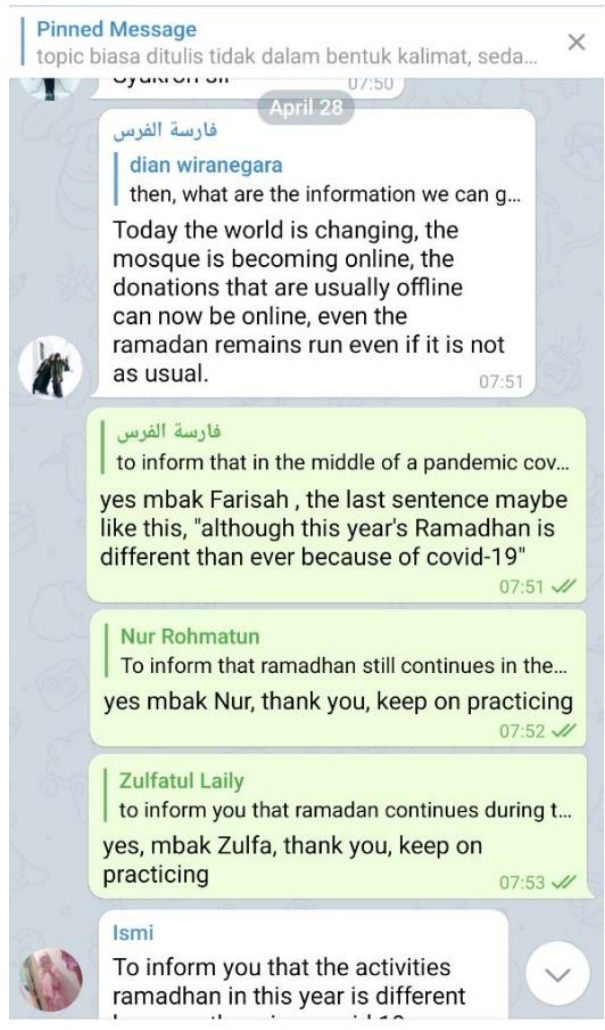

It is done in order that both teacher and all students, in the group, can pay attention to correct as well as to give further feedback towards his or her written opinion within the class. This can be quite long and needs a thorough correction as their writing can be used their references once they practise to give response each other. Therefore, these reading and writing competences can be done simultaneously so that both teacher and students can acquire and practise their respective skills continuously by using the telegram group.

After working on the video by writing their opinion, it is time for the post-teaching by implementing the telegram group. Nonetheless, its process is the same as the post-teach process done in the regular classroom.

\section{Post-Teaching}

Once the students completed the telegram pre-teach and whilst-teach, in the post-teaching, the teacher summed up the lesson by showing the video again. This was done to remind all the information from the video. The participants of this process did not require all students of the class group chat. It only took several students who could effectively regain all the information. Therefore, the topic of the day could be delivered properly for the students. 


\section{JEASP}

Journal of English for Academic and Specific Purposes

Volume 3 Number 2, December, 2020

The next step, before wrapping the class, the teacher handed out another reading text material that can be studied for the preparation of next meeting. This can be shown as follows.

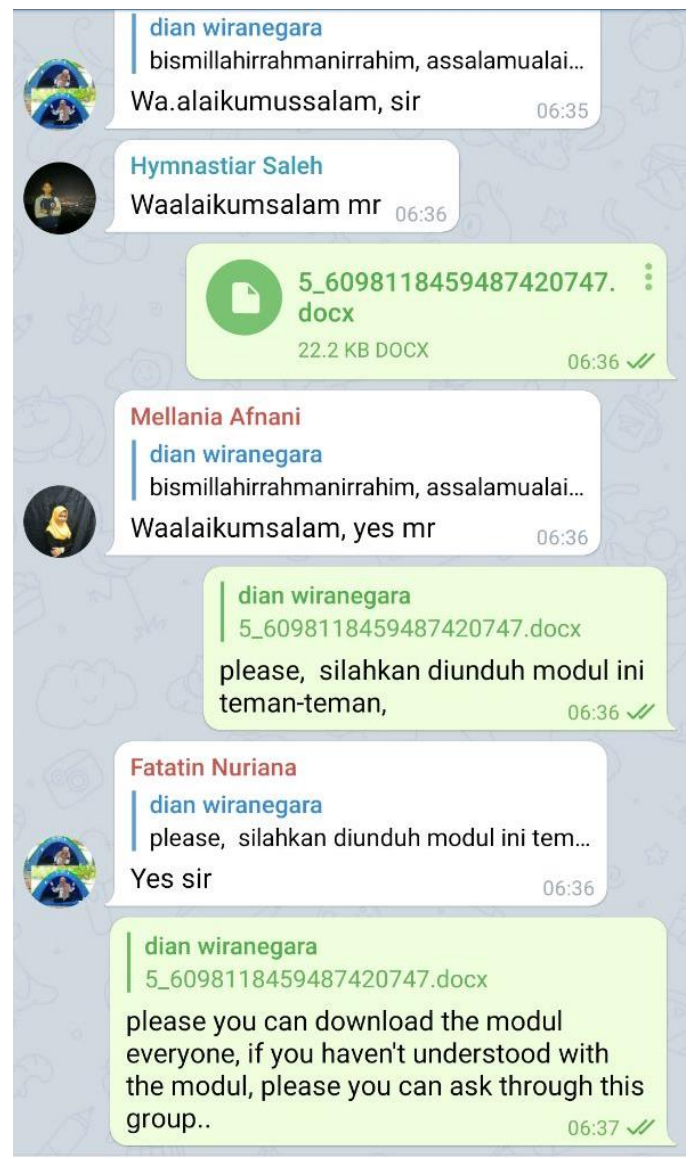

As shown from the screenshot above that the teacher was giving another instruction for the students to read and study the material given the post teach. Therefore, it is expected that all members or the students can take advantage fully to participate in telegram group. Nonetheless, as the teacher has asked to download the reading material and closed the meeting through the group chat, all questions and perhaps another opinion are welcome to be expressed or questions through the group chat.

\section{FINDING AND DISCUSSION}

Based on the activities illustrated above, both teacher and the students have actually taken advantage through the online classroom activities. This is in line with the plan of adapting any learning strategy where both teachers and students can work together to conduct the distance class. Nonetheless, they are not actually left alone to keep the learning process run. For this reason, the 
JEASP

Journal of English for Academic and Specific Purposes

Volume 3 Number 2, December, 2020

social media group learning strategy can be developed to involve as well as to encourage students to be active in the process of teaching and learning.

Though the class is not conducted regularly, students can fully contribute in this process by the help of telegram group class. This social media group can also be used to hold a meeting just like the regular class conducted. Teacher can still observe all members of the group-students-belong to the class once both parties start to chat or to keep online within the chat in telegram group. Therefore, every meeting within the group, teacher can share his teaching material into the group and discuss it along with the students.

The use of telegram mobile application has assisted both teacher and students to reach the objective of this regular class competences. As the program teaches reading and writing as its primary language skills, this mobile application can also insert video files and these files will not disappear as these are stored into the cloud apps. Therefore, telegram has become one of the most famous online social media networks used for teaching and learning process as its intermediary server can actually handle all encryption and communication with the Telegram API for the users. Therefore, this social media application can be helpful to accommodate the teaching and learning process by both teacher and students.

\section{RECOMENDATION}

The use of online madia platform especially teleram in teaching learning procces during pandemic covid 19 is very helpfull both for students and lecturers. Therefore rechercher would like to give some recomendations based on conclusions and researcher activity as follow :

1. Telegram may be not the only one platform to support teachcing and learning prosses, however this platform are proved to reach teaching and leaarning objective during online class, therefore lecturer are abele to apply and use this platform in their activity next semester.

2. Telegram is also able to be used for english teachers.teachers should find the best insturctional media / platform in their online class and choose best startegy during this pandemic. Writer suggest to english teacher that telegram could be best platform used suchs writers does. Becouse it is proved to increase students' intererst during teaching and learning proccess.

3. For further researcher, who has same interest in using telegram to their class during pandemic, this study could be references. 
JEASP

Journal of English for Academic and Specific Purposes

Volume 3 Number 2, December, 2020

\section{REFERENCES:}

Burston, J. (2013). Mobile-assisted language learning: A selected annotated bibliography of implemen tation studies 1994-2012. Language Learning \& Technology, 17(3): 157-225. Retrieved from http://llt.msu.edu/issues/october2013/burston.pdf

Debele, E. T., and Kelbisa, E. M. (2017). The role of active learning methods for classroom participation: the case of first year students of sociology in Samara University. IOSR Journal of Humanities and Social Science, Vol. 22, Issue 7, 2017.

Day, C. (1999) Developing Teachers: the challenges of lifelong learning. London: Falmer Press.

Dumiyati, Wardhono, Agus \& Nurfalah, Edi. (2017). Pengembangan Perangkat Model Pembelajaran English For Specific Purpose (Esp) Berbasis ICT. Makalah. Dalam: Seminar Nasional Hasil Penelitian dan Pengabdian kepada Masyarakat II Universitas PGRI Ronggolawe Tuban, 23 September.

Fennessy, D. (1998) Teachers' Perceptions of the Effects of In-service Education and School Based Support on their Teaching, paper presented at the BERA Annual Conference, Queen's University of Belfast, 27-30 August

Ha Le, Jeroen Janssen \& Theo Wubbels. (2018). Collaborative learning practices: teacher and student perceived obstacles to effective student collaboration, Cambridge Journal of Education, 48:1, 103-122, DOI: 10.1080/0305764X.2016.1259389

Lixun, Wang (2017) Public Lecture Series 2017: The English You Didn't Learn in School

$V$, Mobile Assisted Language Learning. Retrieved from

https://www.ied.edu.hk/ele/pls/spring 2017/seminar4.pdf on June 8th 2017.

Markova, Tatiana, Glazkova, Irina \& Zaborova, Elena. (2016) Quality Issues of Online Distance Learning. $7^{\text {th }}$ International Conference on Intercultural Education "Education Health and ICT for a Transcultural World',15-17 June, 685-691.

Oliveira, L. C. (2015). A language-based approach to content instruction (LACI) for English language learners. Journal of Language and Literacy Education. Retrieved from https://www.google.com/url?sa=t\&source=web\&rct=i\&url=http://jolle.coe.uga.edu/w p-content/uploads/.

Sandholtz, J.H. (2000) Interdisciplinary Team Teaching as a Form of Professional Development, Teacher Education Quarterly, 27(3), pp. 39-54.

Saud, Udin Syaifudin., (2008). Inovasi Pendidikan, Bandung: Alfabeta

Wardhono, Agus \& Spanos, Stephen. (2018). Assessing English Speaking and Listening Skills with The Mobile Application Telegram. Indonesian EFL Journal: Journal of ELT, Linguistics, and Literature, Volume 4, Issue 2: 147-174.

Wringley, H.S. (1998). Knowledge in Action: The Promise of Project-Based Learning. http://www.nesall.net/?id=384. 